\title{
Scientific Achievements of the School of Academician Olexandr O. Bogomolets
}

This article describes the achievements of the pathophysiological school established by Olexandr Olexandrovych Bogomolets (1881-1946)—a brilliant scientist with a broad scientific outlook, founder of the Institute of Clinical Physiology (now the Bogomolets Institute of Physiology in Kyiv). The contribution of the scientific school can be witnessed in the fields of blood transfusion, immunity, reactivity, endocrinology, oncology, and gerontology. Among Bogomolets's students were the famous scientists M. M. Syrotynin, R. Ye. Kavets'kyi, M. M. Horiev, Yu. O. Spasokukots'kyi and others.

Olexandr O. Bogomolets, academician of the National Academy of Sciences of Ukraine, was a great innovator in science, whose ideas were ahead of his time. Bogomolets was the founder of the Ukranian national pathophysiology school and his brilliant research supported studies in many branches of science: physiology, pathophysiology, medicine. Bogomolets had tight collaboration with practicing medical professionals. Cooperation with doctors helped him to establish the Institute of Functional Diagnostics and Experimental Therapy in Moscow in 1925, and the Institute of Clinical Physiology in 1934. The latter became the coordinating research and medical center of doctors in Kyiv.

To characterize the scientific atmosphere in which Bogomolets developed as a scientist, one should cite the professor himself. "My teachers," Bogomolets wrote,

were representatives of different schools. V. V. Pidvysots'kyi and L. O. Tarasevych were followers of Mechnikov. My teacher and friend, M. G. Ushyns'kyi was the disciple of Pashutin and Botkin... I spent my years of associate professorship in the laboratory of V. V. Voronin (who in turn was the student of G. O. Zahar'yin), whose great erudition left me a deep impression. (Bogomolets, 1947)

A talented and creative person, Bogomolets did not only perceive the ideas of his famous predecessors, but also managed to form his own progressive direction in science.

Bogomolets was born on May 24, 1881 in Kyiv. After graduating from the Novorossiysk University (now University of Odessa), he worked at the 
Department of General Pathology as an assistant and associate professor. After defending the doctoral thesis he entered the internship in Sorbonne. In 1911, Bogomolets was selected and approved as Head of the Department of General Pathology and Bacteriology in Saratov University. In 1925-1931, he was professor of the Medical Faculty of the Second Moscow University and at the same time (1928-1931) director of the Institute of Hematology and Blood Transfusion. In 1931, he moved to Kyiv, where founded the Institute of Experimental Biology and Pathology, and in 1934 the Institute of Clinical Physiology.

The scientific school of Bogomolets started to emerge already in Saratov. The basis for the future school formed from his colleagues at the Department of General Pathology_doctors M. Ye. Osokin, M. P. Sokolovs'kyi, P. S. Grygor'yev, $\mathrm{V}$. Grecke and others. It is important to note that most of Bogomolets's students later became well-known professors in various disciplines.

Bogomolets was notorious for his knowledge, wide range of research interests and their implementation in clinical practice (Bogomolets, 1982). The subjects of his scientific work varied between issues of endocrinology, metabolism, immunity, blood circulation pathology, malignant growth processes, gerontology, and so on. In addition, owing to the famine, cholera, typhoid fevers, malaria, etc. in the Volga region at the time, the department led by Bogomolets devoted also considerable attention to issues of sanitation, hygiene and epidemiology (Trudy..., 1917).

In 1925, Bogomolets moved to Moscow, where he held the position of the head of the Department of Pathological Physiology of the Medical Faculty of the Second Moscow University. The scientist devoted a lot of effort and time to training young scientific progeny. This is why assistants M. M. Syrotynin (later academician of the U.S.S.R. and member of the Academy of Sciences of Ukraine), L. R. Perel'man (who took over the department in Leningrad in 1928), and N. B. Medvedeva (member of the Academy of Sciences of Ukraine in Kyiv) moved to Moscow together with their teacher. Soon they were joined by assistant $\mathrm{N}$. D. Yudina and the graduates R. Ye. Kavets'kyi, Y. M. Neiman, M. O. Fedorov, and Ya. G. Uzhans'kyi. A little later, P. D. Horyzontov and M. M. Horiev came to Olexandr Bogomolets for training. In a short time, Horiev, Horyzontov and Fedorov were elected academicians of the U.S.S.R.

Bogomolets was popular among young people. His students and colleagues remember: "Of course, for us Olexander Olexandrovych was not only a teacher, whom we respected. Compared to him we were boys, by age and status, but 
he treated us, the graduate students and later researchers, in a friendly way" (Bogomolets, 1982, p. 108).

In addition to the individuals mentioned above, we should remember professors I. V. Kolpakov, Ye. M. Kohan, M. V. Kolpikov, Ya. H. Uzhans'kyi, who constituted the core of the first generation of Bogomolets's scientific school. Members of the Bogomolets's school eventually headed up to 60 percent of departments of pathophysiology in the former Soviet Union.

With his energetic nature, Bogomolets became engaged not only in scientific, but also organizational work. So, in October 1925 (on the proposal of O. Yu. Shmidt), he established a Department of Experimental Pathology at the Institute of the Nervous Activity Study. In 1926, upon Bogomolets's suggestion, an oncology laboratory was opened at the Moscow City Health Department. There Bogomolets and Y. M. Neiman began to study the antitumor effect of antireticular cytotoxic serum - the ACS, proposed by Bogomolets in Saratov, and known worldwide as 'the Bogomolets serum'. In Kyiv, Bogomolets and his studentsacademician of NAS of Ukraine R. Ye. Kavets'kyi, corresponding member of NAS of Ukraine Oleg Olexandrovych Bogomolets, Yu. O. Spasokukots'kyi, P. D. Marchuk, and others, studied many aspects of the mechanism of action of different doses of ACS, and developed the tests that allow evaluating the functional state of connective tissue (Bogomolets, 1942; Citotoksiny v sovremennoi medicine, 1917).

During the Second World War, Bogomolets, together with his employees, focused all the efforts to help the front. The Institute of Clinical Physiology developed a workpiece and organized shipment of donated blood to the front. Scientists of the Institute went into military hospitals to introduce a new method of blood transfusion proposed by Bogomolets. Also, his antireticular cytotoxic serum proved very effective in treating wounds and bone fractures, and was therefore widely implemented in clinical practice by Bogomolets's students (Istoriya Natsionalnoi..., 2000).

The studies of immunological aspects initiated by Olexander Bogomolets were developed in the Department of Biologically Active Substances, organized in 1960 at the Institute of Physiology of NAS of Ukraine. The organizer and the first head of the Department was Yu. O. Spasokukots'kyi. He studied the physiological features of a body at various stages of aging and developed methods for prevention of premature aging. Bogomolets started experimenting with antiovarian and antitextural sera, on the basis of which the medicines "Proovarin" 
and "Protesticulin" were developed, as well as AOTSS-k, AOTSS-s, to improve the productivity of cattle (Rozvytok patofiziologii..., 2009).

In May 1927, the Bogomolets school began working on a new important problem-blood transfusion. Bogomolets personally, with his students and other staff, developed hemotransfusion and donorship issues which were important for their introduction in medical practice. Bogomolets proposed the theory of the mechanism that stimulates the action of blood transfusion (Bogomolets, 1929).

In the late 1920s and early 1930s, the Soviet biology and medical science were undergoing troubled times. Many major scientists were persecuted. Among them was professor Bogomolets, who was by then famous worldwide and whose name was also well known. As a son of a politically backward non-party authority, he was accused of being influenced by vitalism and "Menchevist idealism" (which emerged at the time). But he persevered and did not resign, as many professors did.

The Kyiv period of Bogomolets's scientific work, which began on April 1, 1931 with him being elected President of National Academy of Sciences of Ukraine, was marked by the flourishing of his scientific school. Bogomolets's disciples followed him from Moscow to Kyiv and were joined by young people from other cities. The representatives of the Bogomolets's school headed the research departments of the Institute and quickly launched a broad scientific activity. His scientific school enlarged due to the formation of the second generation of specialists who were taught by the more advanced students of Olexander Olexandrovych, under his constant supervision. Those were the future academicians A. D. Ado, V. P. Komisarenko, the corresponding member of the NAS of Ukraine Oleg Bogomolets, professors P. D. Marchuk, T. G. Pashaiev, and others.

As noted above, after Bogomolets's arrival in Kyiv, the building of the Institute of Experimental Biology and Pathology of the Commissariat of Ukraine began on the Vynogradna Street. The institute had a main building, vivarium, garage, stables, greenhouses and a fifteen-apartment-house for the employees.

In 1934, the Institute of Experimental Biology and Pathology became the base for the departments of physiology (O. V. Leontovych) and pathophysiology (O. O. Bogomolets) of the Institute of Clinical Physiology of NAS of Ukraine, which was established upon the suggestion of Bogomolets and M. D. Strazhesko. Although the institute did not have its own building, it united leading scientists and physicians, members of the Academy of Sciences of Ukraine, who lived and 
worked in different cities. Factually it was a branch of the Academy of Medical Sciences of Ukraine.

The especially great merit of Bogomolets's school lies in the design of problems of body reactivity (Bogomolets, 1947). Along with his students, Bogomolets devoted his whole life to the research of this problem. Together with Ye. A. Tatarinov, R. Ye. Kavets'kyi, N. B. Medviedieva, P. D. Marchuk, Oleg Bogomolets, Yu. S. Spasokukots' kyi, he started a whole new trend in the pathogenesis and treatment of infectious and non-infectious diseases. His ideas were further elaborated by M. M. Syrotynin, one of his first students, academician of the Academy of Medical Sciences of the U.S.S.R., and a corresponding member of NAS of Ukraine. The important thing is that he himself created a scientific school of pathophysiology. The results of Bogomolet's and his students' research in reactivity and resistance were highlighted in Syrotynin's monograph Evolution of Organism Resistance and Reactivity (1966).

One of the interesting concepts proposed by Bogomolets is the doctrine of connective tissue. The term 'physiological system of connective tissue' was first introduced by Olexander Bogomolets in his 'Constitution and mesenchyme'. Bogomolets believed that connective tissue was not only an elastic skeleton of body but also formed a kind of physiological body system with complex functional manifestations. A functional state of highly differentiated parenchymal elements, local and general reactions of an organism and longevity depended on the state of that system.

At the end of the twentieth century, G. M. Butenko, corresponding member of the Academy of Medical Sciences, conducted a study on the role of connective cell immunity changes in aging and age-emergence of diseases, thus developing the concept of Bogomolets. Also, the works of V. V. Serov and A. B. Shehter serve as an example of national and international interest to the research of Bogomolets on connective tissues (Serov \& Shehter, 1981).

Bogomolets also focused on issues of aging. He created a new understanding of the importance of the mechanism of aging and age-related changes in protein molecules of cell protoplasm (Duplenko, 1985).

Unfortunately, in the 50 years after Bogomolets's death, the doctrine of the physiological system of connective tissue was strongly criticized by the party leadership. Maybe it was because he chose to defend his fellow scientists under Stalin's repressions during the terrible times of totalitarianism. In the 
notorious "Pavlovian session", at which physiology, pathophysiology, medicine and psychology were attacked, using the name of I. P. Pavlov, the concept of the physiological system of connective system also received a negative mark. According to the assertion of the organizers of the session, cerebral cortex must be the main force in all physiological processes, and an incredible amount of nonsense was put forth by the organizers of Pavlovizatsiya in science. There are a lot of works about these processes (Bogomolets, 1992; Bogomolets, O. B., 2011). In this article it is appropriate to mention a meeting of the "Pavlovian Council", established after the notorious session. The meeting of the Council was held on 5-7 July 1952 in Kyiv. Among other things there was discussion of the development of Pavlov's physiological doctrine in Ukraine. Bogomolets's doctrine about connective tissue was named as the reason which prevented the development of this issue. His concept came under severe criticism and the Council recognized it as a failure. Bogomolets was blamed because he allegedly did not acknowledge the main role of a cerebral cortex, which was opposed to Pavlov's teachings about the higher nervous activity.

At the meeting of the Scientific Council, it was noted that professors R. Ye. Kavets' kyi, Oleg O. Bogomolets, M. M. Syrotynin, Yu. O. Spasokukots'kyi, who defended the "false theory" of connective tissue physiology, were trying with that doctrine to reconcile Pavlov's direction in physiology and medicine, but the council strongly criticized the attempts. The disciples of Olexandr Bogomolets, R. Ye. Kavets'kyi and Oleg Bogomolets were forced to admit the erroneous concept (Fiziologicheskaia sistema..., 1941). Moreover, that board meeting took place on 5-7 of July, and its resolution was published already on June 28, 1952, which means that the party leadership knew in advance about the outcome of the meeting.

The oncology issues also were important and undecided, and Bogomolets's students were actively involved in tackling these. As a result of the research, the important role of reactive capabilities of the physiological system of connective tissue in oncogenesis was shown, since the functional activity of connective tissue in cancer has almost always been low. In order to stimulate the functional activity, Bogomolets proposed an antireticular cytotoxic serum, which gained a wide practical application. Its effectiveness was proven in treating post-operative complications (metastasis) after cancer, in the treatment of mastitis, bone fractures and other conditions (Bogomolets, 1942; Citotoksiny v sovremennoi medicine, 1956-1972). This is the course in which the students of Bogomolets, academicians of Ukraine R. Ye. Kavets'kyi and Z. A. Butenko worked. 
After the Pavlovian session, clinicians stopped using the antireticular cytotoxic serum, because it was compared with the concept of the physiological system of connective system, which was claimed as the reactionary doctrine.

Regardless of that, Bogomolets's scientific legacy was not lost. The Institute of Physiology, despite the ideological pressure during its creation, became a powerful center of scientific physiological studies. Research conducted at the institute under the guidance of P. G. Kostiuk became highly valued all over the world. Kostiuk managed to save the course of research initiated by Bogomolets and develop new advanced areas of physiology—neurophysiology, electrophysiology, molecular biology, and others.

A few words must be said about the Bogomolets medical family dynasty, which is one of the oldest of its kind in Ukraine. The founder of this dynasty was Olexander Mihailovich Bogomolets (1850-1935), a local doctor, and his wife Sofia Nikolaevna. Academician Olexander was their son. Oleg Bogomolets (1911-1991), son of Olexandr, continued his father's work. For some time he was director of the Institute of Experimental Biology and Pathology of the Ministry of Health of the U.S.S.R. After the abovementioned Pavlovian session, the Institute of Clinical Physiology and the Institute of Experimental Biology and Pathology were merged into the Institute of Physiology. In 1953, Oleg Bogomolets became head of the Laboratory of Pathophysiology at the Ukrainian Research Institute of Pharmacology and Toxicology, which he led until 1980.

Oleg Bogomolets's daughter Katerina was professor of the Department of Pathology of the Bogomolets National Medical University. She worked as an anesthesiologist at the Institute of Tuberculosis and Thoracic Surgery, led by the renowned cardiac surgeon, Academician Nikolai Amosov. Her sister Olexandra worked as a pediatrician of resuscitation.

Olga Bogomolets, daughter of Katerina and Vadim Berezovsky, is an honored dermatologist and professor at the Bogomolets National Medical University (Bogomolets, O. B., 2011). She was actively involved in medical support for the Euromaidan in Kyiv during the 2013-2014 political crisis in Ukraine.

\section{Ludmila O. Klimenko}

Bogomolets National Medical University 


\section{References}

Bogomolets, A. A. (1929), 'Nauchnoe i prakticheskoe znachenie metoda perelivaniia krovi,' Nauchnoe slovo, no. 8, pp. 35-64.

(1942), 'Antiretikuliarnaia cytotoksicheskaia syvorotka kak sredstvo patogeneticheskoi terapii,' O lechebnom deistvii antiretikuliarnoi cytotoksicheskoi syvorotki “ACS”, Ufa: Isd-vo AN USSR, pp. 9-29; 133-152.

— (1947), 'Osnovnye napravleniia moikh rabot,' Arh. patologii, vol. 9, no. 3, pp. 3-14. (1982), Vospominaniia sovremennikov, Kyiv: Nauk. dumka, pp. 134-137.

(1992), 'Nauchnaya shkola Alexandra Alexandrovicha Bogomoltsa,' in O. O. Bogomolets (ed.) Matematicheskoe estestvoznanie / Fragmenty istorii. Sb. nauchnuch trudov, Kyiv: Nauchnaya dumka, pp. 247-291.

Bogomolets, O. B. (2011), 'Dlya nastoyashtego vracha net nichego interesnee ego profesii,' Zdorov'ya Ukrainu, no. 6 (259), pp. 42-43.

Citotoksiny v sovremennoi medicine (1956-1972), vols. 1-6, Kyiv: Gosmedizdat USSR.

Duplenko, Y. K. (1985), Starenie: Ocherki razvitiya problem, Leningrad: Nauka.

Fiziologicheskaia sistema soedinitel'noi tkani (1941), Tr. konf., Kyiv, dek. 1940, Kyiv: Iztvo AN USSR.

Istoriya Natsionalnoi akademii nauk Ukrainu v suspilno-polituchnomu konteksti 19181998 (2000), ed. by Y. Chramova, Kyiv: Feniks, 2000.

Klimenko, L. O. (2005), Rozvytok fiziologii nervovoyi systemy v Ukrajini v 40-60-h rokah XX stolittia, Avtoref. dys....kan.ist.nauk [In Ukrainian].

'Postanova VII sessii naukovoi rady po problemah fiziologichnogo vchennia akademika I. P. Pavlova pry Prezydii Akademii nauk SRSR 7 chervnia 1952 r.,' (1952), Medychnyi zhurn. [in Ukrainian], vol. 22, no. 4, pp. 3-4.

Rozvytok patofiziologii v Ukrayini (2009), [in Ukrainian] Za red. akademika NAN Ukrayiny O. O. Moybenka, Chernivci.

Serov, V. V. \& Shehter, A. B. (1981), Soedinitelnaia tkan (funktsionalnaia morfologiia $i$ obshchaia patologiia, Moscow: Medgiz.

Trudy laboratorii obshchei patologii Saratovskogo universiteta (1917), vols. 1-2, Saratov: Saratovskii universitet. 